\title{
Survey of the fatty acid composition of retail milk differing in label claims based on production management practices ${ }^{1}$
}

\author{
A. M. O’Donnell, ${ }^{*}$ K. P. Spatny, ${ }^{*}$ J. L. Vicini,† and D. E. Bauman*² \\ *Department of Animal Science, Cornell University, Ithaca, NY 14853 \\ †Monsanto Co., St. Louis, MO 63167
}

\begin{abstract}
Consumers are becoming increasingly health conscious, and food product choices have expanded. Choices in the dairy case include fluid milk labeled according to production management practices. Such labeling practices may be misunderstood and perceived by consumers to reflect differences in the quality or nutritional content of milk. Our objective was to investigate nutritional differences in specialty labeled milk, specifically to compare the fatty acid (FA) composition of conventional milk with milk labeled as recombinant bST (rbST)-free or organic. The retail milk samples ( $\mathrm{n}=292$ ) obtained from the 48 contiguous states of the United States represented the consumer supply of pasteurized, homogenized milk of 3 milk types: conventionally produced milk with no specialty labeling, milk labeled rbST-free, and milk labeled organic. We found no statistical differences in the FA composition of conventional and rbST-free milk; however, these 2 groups were statistically different from organic milk for several FA. When measuring FA as a percentage of total FA, organic milk was higher in saturated FA (65.9 vs. $62.8 \%)$ and lower in monounsaturated FA (26.8 vs. $29.7 \%$ ) and polyunsaturated FA (4.3 vs. $4.8 \%$ ) compared with the average of conventional and rbSTfree retail milk samples. Likewise, among bioactive FA compared as a percentage of total FA, organic milk was slightly lower in trans $18: 1 \mathrm{FA}$ (2.8 vs. $3.1 \%$ ) and higher in n-3 FA (0.82 vs. $0.50 \%)$ and conjugated linoleic acid (0.70 vs. $0.57 \%)$. From a public health perspective, the direction for some of these differences would be considered desirable and for others would be considered undesirable; however, without exception, the magnitudes
\end{abstract}

\footnotetext{
Received October 6, 2009.

Accepted January 8, 2010.

${ }^{1}$ Supported in part by the Cornell Agricultural Experiment Station and Monsanto Company. Also supported in part by the Cooperative State Research, Education, and Extension Service, USDA, under Agreement No. NYC-127437. Any opinions, findings, conclusions or recommendations expressed in this publication are those of the authors and do not necessarily reflect the view of the USDA.

${ }^{2}$ Corresponding author: deb6@cornell.edu
}

of the differences in milk FA composition among milk label types were minor and of no physiological importance when considering public health or dietary recommendations. Overall, when data from our analysis of FA composition of conventional milk and milk labeled rbST-free or organic were combined with previous analytical comparisons of the quality and composition of these retail milk samples, results established that there were no meaningful differences that would affect public health and that all milks were similar in nutritional quality and wholesomeness.

Key words: fatty acid composition, human health, organic, recombinant bST

\section{INTRODUCTION}

Nutritional quality is an important consideration when making food choices. Milk is an excellent source of many essential nutrients and supplies the body with energy, high-quality protein, and a variety of the required vitamins and minerals (Huth et al., 2006). In addition, consumers are increasingly aware that some food components may have long-term effects on human health. Fats are of special interest, and milk fat is considered a saturated fat because of its fatty acid (FA) profile. Among the individual FA in milk fat, several such as n-3 FA and conjugated linoleic acids (CLA) may have beneficial effects on health maintenance and the prevention of acute and chronic diseases (Lock and Bauman, 2004; Bauman et al., 2006; German and Dillard, 2006). Dietary intake of other FA, such as some of the individual saturated fatty acids (e.g., lauric, myristic, and palmitic acids) and the trans-18:1 fatty acids (TFA), is considered a risk factor in coronary heart disease (Lock et al., 2005; Parodi, 2009).

In recent years, grocery stores have expanded their dairy case selection to include milk products with label claims related to agricultural management practices. In addition to conventionally produced milk, retail choices often include milk labeled as recombinant bST (rbST)free and organic. Consumers have little knowledge of how milk is produced, and the information search for most Americans rarely extends beyond package label- 
ing and retail marketing. Of particular concern is that some consumers may perceive that this type of specialty labeling indicates differences in the quality, nutritional value, or safety of dairy foods. Vicini et al. (2008) recently conducted a survey that compared retail samples of conventional milk with milk labeled as rbST-free or organic; they found that there were no meaningful differences in quality (antibiotics and bacterial counts), gross composition (fat, protein, and solids-not-fat), or hormone concentrations (including bST, estrogen, and insulin-like growth factor-1) among the retail milk samples with these labels. The milk fat content and fatty acid profile can be markedly affected by management practices, especially through ration formulation and use of specific dietary components (Palmquist et al., 1993; Chilliard et al., 2000; Jensen, 2002). Our specific objective was to compare the fatty acid profile of conventional milk with retail milk samples labeled as rbST-free and organic. Bioactive FA such as n-3 FA, CLA, and TFA were of special interest as were the overall profile and distribution of saturated and unsaturated fatty acids.

\section{MATERIALS AND METHODS}

\section{Sampling Methods}

Milk samples used in the present investigation were those described for the study by Vicini et al. (2008). Briefly, retail milk samples were obtained from stores within the 48 contiguous United States during a 3-wk period in October and November 2006, and purchased in blocks to minimize effects of shipping conditions. Blocks contained one each of the following label types: conventional, rbST-free, and organic. Conventional milk samples were those that had no label claims regarding rbST use or production practices. Milk labeled rbST-free included a label claim that cows were not supplemented with rbST, and milk labeled as organic originated from farms certified to meet USDA standards for organic production. Purchasers were Monsanto Company employees working in each state. States producing larger volumes of milk or those with higher populations were oversampled to more accurately represent the overall milk supply within the United States, and samples were selected with the following considerations: 1) whole milk for fat analysis; 2) freshest milk based on expiration date; and 3) paper or plastic container. Unpasteurized milk and milk labeled as using UHT pasteurization were excluded to minimize processing differences among samples. Further details on sampling and storage are given in an earlier publication (Vicini et al., 2008). For the present study, sample aliquots were shipped frozen overnight to Cornell University (Ithaca, NY) and stored frozen at $-20^{\circ} \mathrm{C}$ until processed for FA analysis.

\section{Fatty Acid Analysis}

Extraction of milk fat was based on the method of Hara and Radin (1978), and transmethylation of the esterified FA was according to Christie (1982) as modified by Chouinard et al. (1999). Briefly, hexane:isopropanol was used to extract the milk fat, and sodium methoxide served as the methylation reagent. Fatty acid methyl esters were quantified by gas chromatography (Hewlett Packard GCD system HP 6890+, Hewlett-Packard, Avondale, PA) fitted with a CP-Sil 88 fused-silica capillary column $(100 \mathrm{~m} \times 0.25 \mathrm{~mm}$ i.d. with $0.2 \mu \mathrm{m}$ film thickness; Varian Instruments, Walnut Creek, CA). The initial oven temperature was set at $80^{\circ} \mathrm{C}$ and increased to $190^{\circ} \mathrm{C}$ at $2^{\circ} \mathrm{C} / \mathrm{min}$ and maintained for $20 \mathrm{~min}$, then increased to $225^{\circ} \mathrm{C}$ at $10^{\circ} \mathrm{C} / \mathrm{min}$ and maintained for 12 min. Fatty acid peaks were identified and recoveries quantified using pure methyl ester standards (GLC569, NuChek Prep, Elysian, MN). In addition, a butter oil reference standard (CRM 164; Commission of the European Communities, Community Bureau of Reference, Brussels, Belgium) was periodically analyzed as a control to verify column performance and correction factors for individual FA.

\section{Statistical Analysis}

The FA composition of the milk samples $(\mathrm{n}=292)$ was used for statistical analysis. Data were analyzed using JMP 7.0 (SAS Institute Inc., Cary, NC); treatment groups - conventional $(\mathrm{n}=111)$, rbST-free $(\mathrm{n}=82)$, and organic $(\mathrm{n}=99)$ labeled milk-were included in the model as a fixed effect and shipping block $(\mathrm{n}=123)$ as a random effect. Least squares means were reported using Tukey's test for detecting differences between treatment means, and significance was declared when $P$ $<0.05$. For some FA, variances were declared unequal by Levene's test and thus analyzed using SAS 9.0 (SAS Institute Inc.) to allow for unequal variances and report individual variance estimates for each treatment group. Significance was declared when $P<0.05$.

\section{RESULTS AND DISCUSSION}

In an effort to increase market share and offer choice to consumers, retailers often stock the dairy case with milk with specialty labels based on production practices. In the present study, we compared the FA composition of conventional milk containing no specialty labeling with retail milk samples labeled as rbST-free or organic. Recombinant bST is a biotechnology product that regulates nutrient partitioning in lactating cows (Bauman, 1999). Administration of rbST increases milk production and improves efficiency so that feed 
resource input, animal waste output, and environmental impact per unit of milk are reduced (National Research Council, 1994; Capper et al., 2008). Since FDA approval of rbST for commercial use in 1993, over 30 million US cows have received rbST supplements, but no test or milk difference can detect rbST use. Thus, the rbST-free label is based on a farmer affidavit indicating that this supplement was not used. Milk that is labeled organic comes from dairy farms that have been certified as following production practices for livestock as outlined in the USDA Organic Standards (USDA/ Agricultural Marketing Service, 2009). These include production management practices such as no use of antibiotics for the treatment of sick animals, no use of pesticides in the production of feedstuffs, and no use of particular management technologies including transgenic products such as rbST or genetically modified crops. As with rbST-free milk, there is no test that can differentiate organic milk; thus, verification is enforced by a third-party certification system.

Milk FA profiles were remarkably similar among label types (Table 1). Conventional and rbST-free milks were not statistically different; thus, for discussion purposes, values presented in the text represent an average of these 2 milk types compared with organic milk. Milk labeled as organic was significantly higher in saturated fatty acids (SFA; 65.9 vs. $62.8 \% ; P<0.001$ ) and lower in monounsaturated fatty acids (MUFA; 26.8 vs. $29.7 \%$; $P<0.001$ ) and polyunsaturated fatty acids (PUFA; 4.3 vs. $4.8 \% ; P<0.001)$ compared with conventional and rbST-free milk (Figure 1). This pattern is less desirable from a public health perspective, but the differences were relatively minor. Among the TFA isomers, trans-11 18:1 predominated for all milk types, and its concentration was greater in milk labeled organic compared with conventional and rbST-free milk samples (1.71 vs. $1.46 \% ; P<0.001$; Figure 2 ). In contrast, the opposite was true for trans-10 18:1. Although variation in trans-10 18:1 supply within the physiological range has no direct effect on milk fat synthesis (Lock et al., 2007), it is associated with alterations in rumen biohydrogenation of dietary PUFA that are characteristic of diet-induced milk fat depression (Harvatine et al., 2009). Thus, increases in trans-10 18:1 content of milk fat are correlated with reductions in the de novo synthesized FA (4:0 to 16:0) that represent the bulk of the SFA content of milk fat (Shingfield and Griinari, 2007; Harvatine et al., 2009). In the present study we saw a pattern consistent with this, in which the milk fat content of trans-10 18:1 was greater and concentrations of FA chain length 4:0 to 16:0 carbons and total SFA were lower in the milk fat from conventional and rbSTfree milk samples compared with the organic samples. However, for all SFA and TFA, differences in milk fat content among label types were minor and of no physiological importance when considering public health or dietary recommendations.

Saturated fatty acids and TFA are considered detrimental to human health because these FA have been associated with a higher risk of coronary heart disease (CHD; National Research Council, 1989; US Department of Health and Human Services/USDA, 2005). To a large extent, the content of SFA and TFA in milk fat is the basis for the perception that milk and dairy products are associated with a higher risk of CHD. However, recent epidemiological studies and dietary intervention trials challenge this perception, and the available evidence does not support the concept that consumption of dairy products represents an increased risk of CHD (Elwood et al., 2004; German et al., 2009; Parodi, 2009). Furthermore, 12:0, 14:0, and 16:0 are specific SFA that increase plasma low-density lipoprotein (LDL) cholesterol levels, a plasma cholesterol fraction associated with increased risk of CHD (Mensink et al., 2003); retail milk labeled organic had higher concentrations of these FA compared with conventional and rbST-free milks (43.1 vs. $40.3 \%$ of total milk FA; $P<0.001)$. However, these specific FA also increase plasma high-density lipoprotein (HDL) cholesterol, a plasma fraction associated with lower risk of CHD, thus partially offsetting the negative effect of increased LDL cholesterol (Mensink et al., 2003; Parodi, 2009). A meta-analysis of the effects of these FA using data from 60 clinical studies demonstrated that the plasma ratio of total cholesterol to HDL cholesterol provided little evidence that dietary intake of 12:0, 14:0, and 16:0 represented an atherogenic risk compared with an isocaloric substitution of carbohydrate (Mensink et al., 2003).

Approximately $80 \%$ of human dietary intake of TFA is from industrial sources because of the use of partially hydrogenated vegetable oils in margarine and in baking and manufacturing of other foods (FDA, 2009). The remaining $20 \%$ comes from natural sources represented by dietary intake of dairy products and meat from ruminants. Industrial and natural sources differ in isomer distribution of 18:1 TFA; the TFA in partially hydrogenated vegetable oil has a Gaussian distribution of isomers centering on trans-9 and trans-10 18:1 (Lock et al., 2005; Destaillats et al., 2008). In contrast, natural TFA consists mainly of trans-11 18:1. In the present study, 18:1 TFA represented $2.8 \%$ of total FA in the milk fat from organic samples, of which $61.1 \%$ was trans-11 18:1; similar values for conventional and rbSTfree milk averaged 3.1 and $47.4 \%$, respectively (Table 1). However, the CHD health concern from consumption of TFA is associated with industrial sources. A plot of the data from published epidemiological studies 


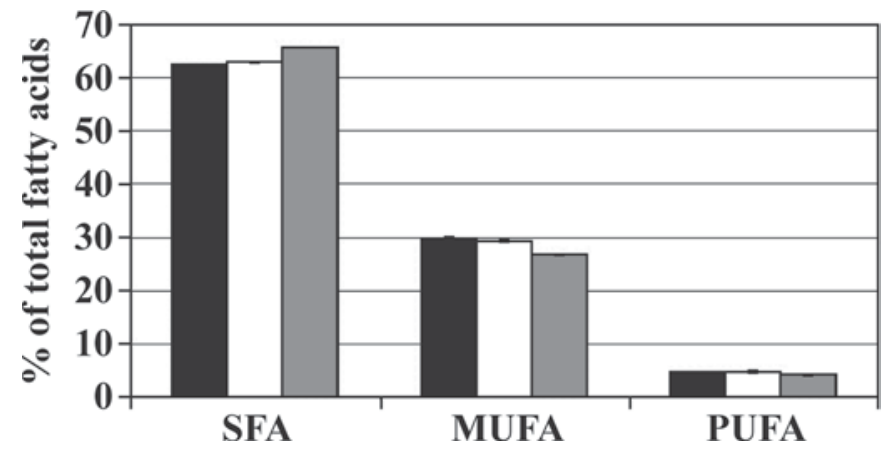

Figure 1. Fatty acid composition of conventional milk samples and retail milk samples labeled as recombinant bST (rbST)-free and organic. Bar graphs are coded for conventional (black), rbST-free (white), and organic (gray) milks with grouping representing saturated fatty acids (SFA), monounsaturated fatty acids (MUFA), and polyunsaturated fatty acids (PUFA). Standard error bars for each treatment bar were too small to show properly, but expressed as a percentage of total fatty acids were $0.22 \%$ for SFA, $0.20 \%$ for MUFA, and $0.07 \%$ for PUFA. demonstrates an increased risk of CHD with increasing dietary intake of industrial TFA (Lock et al., 2005). In contrast, this is not observed for natural sources of TFA and to date, there is no scientific evidence to indicate that naturally occurring TFA are detrimental to human health [see reviews by Jakobsen et al. (2008) and Stender et al. (2008)]. Nevertheless, trans fats and SFA are included on food labels because of concerns about their potential health effects.

Conjugated linoleic acid (cis-9, trans-11 18:2 CLA) is a bioactive FA present in milk fat that has anticarcinogenic and antiatherogenic effects (Bauman et al., 2006). It is formed as an intermediate in rumen biohydrogenation of dietary PUFA; however, most CLA in milk fat is endogenously synthesized in the mammary gland by $\Delta^{9}$-desaturase with the substrate being trans-11 18:1, another rumen biohydrogenation intermediate (Bauman and Lock, 2006). In the present study, CLA content was greater in milk labeled organic compared with conventional and rbST-free milk (Table 1). However, the average CLA content was relatively low for all label

Table 1. Fatty acid composition (\% of total fatty acids) of retail milk samples with labels representing different production management practices

\begin{tabular}{|c|c|c|c|c|}
\hline \multirow[b]{2}{*}{ Variable } & \multicolumn{3}{|c|}{ Treatment $^{1}$} & \multirow[b]{2}{*}{$P$-value 2} \\
\hline & Conventional & rbST-free & Organic & \\
\hline $\mathrm{C} 4: 0$ & $4.17 \pm 0.03^{\mathrm{b}}$ & $4.22 \pm 0.03^{\mathrm{b}}$ & $4.36 \pm 0.03^{\mathrm{a}}$ & $<0.001$ \\
\hline $\mathrm{C} 6: 0$ & $2.12 \pm 0.01^{\mathrm{b}}$ & $2.11 \pm 0.01^{\mathrm{b}}$ & $2.30 \pm 0.01^{\mathrm{a}}$ & $<0.001$ \\
\hline $\mathrm{C} 8: 0$ & $1.15 \pm 0.01^{\mathrm{b}}$ & $1.13 \pm 0.01^{\mathrm{b}}$ & $1.26 \pm 0.01^{\mathrm{a}}$ & $<0.001$ \\
\hline $\mathrm{C} 10: 0$ & $2.53 \pm 0.02^{\mathrm{b}}$ & $2.49 \pm 0.02^{\mathrm{b}}$ & $2.81 \pm 0.02^{\mathrm{a}}$ & $<0.001$ \\
\hline $\mathrm{C} 12: 0$ & $2.89 \pm 0.03^{\mathrm{b}}$ & $2.83 \pm 0.02^{\mathrm{b}}$ & $3.24 \pm 0.03^{\mathrm{a}}$ & $<0.001$ \\
\hline C14:0 & $9.63 \pm 0.06^{\mathrm{b}}$ & $9.42 \pm 0.05^{\mathrm{c}}$ & $10.62 \pm 0.06^{\mathrm{a}}$ & $<0.001$ \\
\hline $\mathrm{C} 14: 1$, cis-9 & $0.89 \pm 0.01^{\mathrm{b}}$ & $0.87 \pm 0.01^{\mathrm{b}}$ & $0.98 \pm 0.01^{\mathrm{a}}$ & $<0.001$ \\
\hline C15:0 & $0.90 \pm 0.01^{\mathrm{b}}$ & $0.87 \pm 0.01^{\mathrm{c}}$ & $1.07 \pm 0.01^{\mathrm{a}}$ & $<0.001$ \\
\hline $\mathrm{C} 16: 0$ & $27.99 \pm 0.13^{\mathrm{b}}$ & $27.78 \pm 0.09^{\mathrm{b}}$ & $29.27 \pm 0.17^{\mathrm{a}}$ & $<0.001$ \\
\hline $\mathrm{C} 16: 1$, cis-9 & $1.55 \pm 0.02^{\mathrm{a}}$ & $1.53 \pm 0.01^{\mathrm{a}}$ & $1.47 \pm 0.02^{\mathrm{b}}$ & 0.003 \\
\hline $\mathrm{C} 17: 0$ & $0.50 \pm<0.01^{\mathrm{b}}$ & $0.50 \pm<0.01^{\mathrm{b}}$ & $0.55 \pm<0.01^{\mathrm{a}}$ & $<0.001$ \\
\hline C18:0 & $10.88 \pm 0.10^{\mathrm{a}}$ & $11.04 \pm 0.08^{\mathrm{a}}$ & $10.21 \pm 0.12^{\mathrm{b}}$ & $<0.001$ \\
\hline C18:1, trans $-6-8$ & $0.29 \pm 0.01^{\mathrm{a}}$ & $0.30 \pm<0.01^{\mathrm{a}}$ & $0.22 \pm<0.01^{\mathrm{b}}$ & $<0.001$ \\
\hline $\mathrm{C} 18: 1$, trans-9 & $0.28 \pm<0.01^{\mathrm{a}}$ & $0.29 \pm<0.01^{\mathrm{a}}$ & $0.21 \pm<0.01^{\mathrm{b}}$ & $<0.001$ \\
\hline $\mathrm{C} 18: 1$, trans -10 & $0.52 \pm 0.02^{\mathrm{a}}$ & $0.55 \pm 0.01^{\mathrm{a}}$ & $0.28 \pm 0.01^{\mathrm{b}}$ & $<0.001$ \\
\hline $\mathrm{C} 18: 1$, trans- 11 & $1.45 \pm 0.02^{\mathrm{b}}$ & $1.47 \pm 0.02^{\mathrm{b}}$ & $1.71 \pm 0.05^{\mathrm{a}}$ & $<0.001$ \\
\hline $\mathrm{C} 18: 1$, trans -12 & $0.50 \pm 0.01^{\mathrm{a}}$ & $0.52 \pm 0.01^{\mathrm{a}}$ & $0.38 \pm 0.01^{\mathrm{b}}$ & $<0.001$ \\
\hline $\mathrm{C} 18: 1$, cis-9 & $23.90 \pm 0.14^{\mathrm{b}}$ & $24.38 \pm 0.09^{\mathrm{a}}$ & $21.44 \pm 0.11^{\mathrm{c}}$ & $<0.001$ \\
\hline $\mathrm{C} 18: 2, \mathrm{n}-6$ & $3.50 \pm 0.06^{\mathrm{a}}$ & $3.43 \pm 0.04^{\mathrm{a}}$ & $2.55 \pm 0.08^{\mathrm{b}}$ & $<0.001$ \\
\hline $\mathrm{C} 20: 0$ & $0.09 \pm<0.01^{\mathrm{b}}$ & $0.09 \pm<0.01^{\mathrm{b}}$ & $0.10 \pm<0.01^{\mathrm{a}}$ & $<0.001$ \\
\hline $\mathrm{C} 18: 3, \mathrm{n}-3$ & $0.41 \pm 0.01^{\mathrm{b}}$ & $0.40 \pm 0.01^{\mathrm{b}}$ & $0.65 \pm 0.01^{\mathrm{a}}$ & $<0.001$ \\
\hline $\mathrm{C} 18: 2$, cis- 9 , trans -11 & $0.57 \pm 0.01^{\mathrm{b}}$ & $0.57 \pm 0.01^{\mathrm{b}}$ & $0.70 \pm 0.02^{\mathrm{a}}$ & $<0.001$ \\
\hline $20: 4, \mathrm{n}-6$ & $0.14 \pm<0.01^{\mathrm{a}}$ & $0.14 \pm<0.01^{\mathrm{a}}$ & $0.11 \pm<0.01^{\mathrm{b}}$ & $<0.001$ \\
\hline $20: 5, \mathrm{n}-3$ & $0.03 \pm<0.01^{\mathrm{b}}$ & $0.03 \pm<0.01^{\mathrm{b}}$ & $0.06 \pm<0.01^{\mathrm{a}}$ & $<0.001$ \\
\hline $22: 5, \mathrm{n}-3$ & $0.06 \pm<0.01^{\mathrm{b}}$ & $0.06 \pm<0.01^{\mathrm{b}}$ & $0.11 \pm<0.01^{\mathrm{a}}$ & $<0.001$ \\
\hline $22: 6, \mathrm{n}-3$ & $\mathrm{ND}^{3}$ & ND & ND & - \\
\hline Other & $2.95 \pm 0.04^{\mathrm{b}}$ & $2.94 \pm 0.03^{\mathrm{b}}$ & $3.17 \pm 0.03^{\mathrm{a}}$ & $<0.001$ \\
\hline
\end{tabular}

${ }^{\mathrm{a}-\mathrm{c}}$ Differences within a row are indicated by different superscript letters.

${ }^{1}$ Treatment groups were conventional milk samples (no label claims regarding production management practices) and retail milk samples labeled as recombinant bST (rbST)-free and as organic. Values represent least squares means $\pm \mathrm{SE}$ for retail milk samples $(\mathrm{n}=292)$.

${ }^{2}$ Probability of significant differences among treatment groups.

${ }^{3} \mathrm{ND}=\operatorname{not}$ detected $(<0.01 \%$ of total fatty acids $)$. 
groups (5.7 to $7.0 \mathrm{mg}$ of CLA/g of FA), and differences among milk sources were relatively minor, having little or no implications for human health.

The benefits of CLA in health maintenance and the prevention of chronic diseases have been established in biomedical studies with animal models; extrapolation of CLA doses from these studies indicates that the benefits would occur if the CLA content of milk fat was at levels 4- to 6-fold greater than those observed for all retail samples in the present study (Parodi, 2003; Bauman et al., 2006). The CLA content of milk fat can be markedly affected by diet and this is probably the reason for the variation among milk samples within label groups, especially for the organic group (Figure 3 ). Organic producers are required to provide cows access to pasture, and pasture is a dietary component that may increase milk fat content of CLA. However, this effect is most pronounced when cows are grazing lush pasture, and effects are mitigated as the pasture matures or the diet includes additional feedstuffs (Kelly et al., 1998; Auldist et al., 2002).

The n-3 FA are essential for optimal health and the prevention of chronic and acute diseases (Yashodhara et al., 2009). In milk, $\alpha$-linolenic acid (ALA) is the predominant n-3 FA and it was at a greater concentration in milk labeled organic compared with conventional and rbST-free milk (0.65 vs. $0.41 \%$, respectively; Table 1 ). However, these concentrations are very low and represent a minimal contribution to the dietary requirements of humans (Kris-Etherton et al., 2009). Furthermore, eicosapentaenoic acid (EPA) and docosahexaenoic acid (DHA) are the n-3 FA that are important in health maintenance and the prevention of chronic and acute diseases (Lavie et al., 2009; Yashodhara et al., 2009). Human clinical studies have shown that the conversion of ALA to EPA or DHA is very limited in adults and children (Arterburn et al., 2006; Brenna et al., 2009); therefore, the dietary recommendation for adult humans is $500 \mathrm{mg} / \mathrm{d}$ for EPA + DHA, irrespective of ALA consumption (Gebauer et al., 2006; Kris-Etherton et al., 2009).

Previous studies from other countries have compared the CLA and n-3 FA contents of organic and conventional milk. These have typically involved comparisons of individual farms and often only small sample sizes; none has examined labeled retail milk in a manner comparable to the present study. Some of these investigations have reported greater CLA content in milk from organic farms (Bergamo et al., 2003; Kraft et al., 2003), whereas others report differences in n-3 FA but not in the CLA content of milk fat (Ellis et al., 2006; Butler et al., 2008; Molkentin, 2009). These inconsistent results are most likely related to the use of milk from controlled, farm-level experiments rather than retail

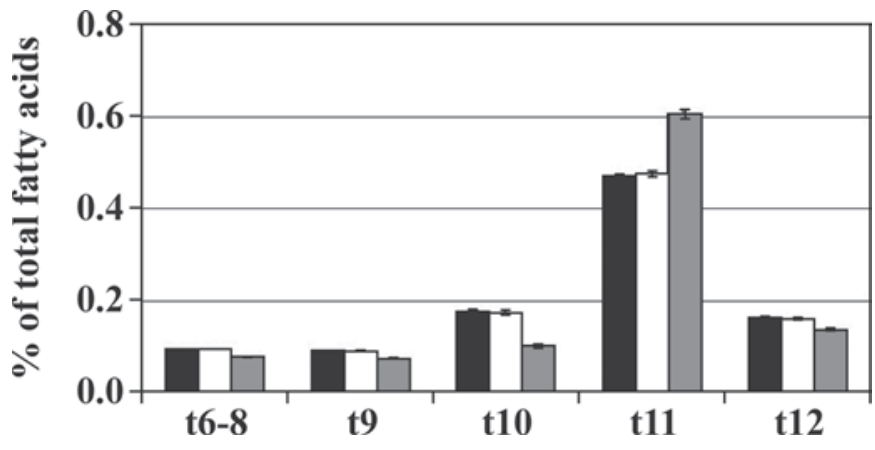

Figure 2. Fatty acid composition for the trans 18:1 isomers in conventional milk samples and retail milk samples labeled as recombinant bST (rbST)-free and organic. Bar graphs are coded for conventional (black), rbST-free (white), and organic (gray) milks. Standard error bars for some treatment groups were too small to show properly, but all were $<0.01 \%$ of total fatty acids.

milk that would represent pooled milk as purchased by consumers. In practice, organic farms as well as conventional farms can vary widely in feeding and diet formulations. This variation was clearly demonstrated in a study by Molkentin (2009) who compared the n-3 FA milk fat content from 3 retail sources of organic and conventional milk, as well as one individual organic farm, every other week for 18 mo. The individual organic farm had the highest and the lowest n-3 FA values compared with the organic retail samples over the duration of the study, illustrating the substantial variation that exists with single-farm sampling. The variation observed in the present study for n-3 and CLA content of milk fat in retail samples is also likely because of diet differences (Figure 3). Nevertheless, across all farm- or retail-based studies that have compared organic with conventional milks, any differences that were observed in FA composition were small and not of a magnitude to have human health implications.

The present study is among the first to investigate differences in the fatty acid profiles of specialty labeled retail milk samples. Milk labeled rbST-free was not statistically different from conventional milk, but there were statistical differences between milk labeled organic and the conventional and rbST-free retail samples. Some of these differences could be considered desirable and some less desirable, but without exception, the differences among conventional milk and milk labeled as rbST-free or organic were minor and unlikely to be of public health relevance. Milk FA profile is mainly affected by dietary components and formulations rather than by production management practices. It is possible to use common feedstuffs to achieve a CLA content in milk fat that may aid in the prevention of chronic diseases, especially when total mixed rations are supplemented with plant or fish oils that are high in PUFA 

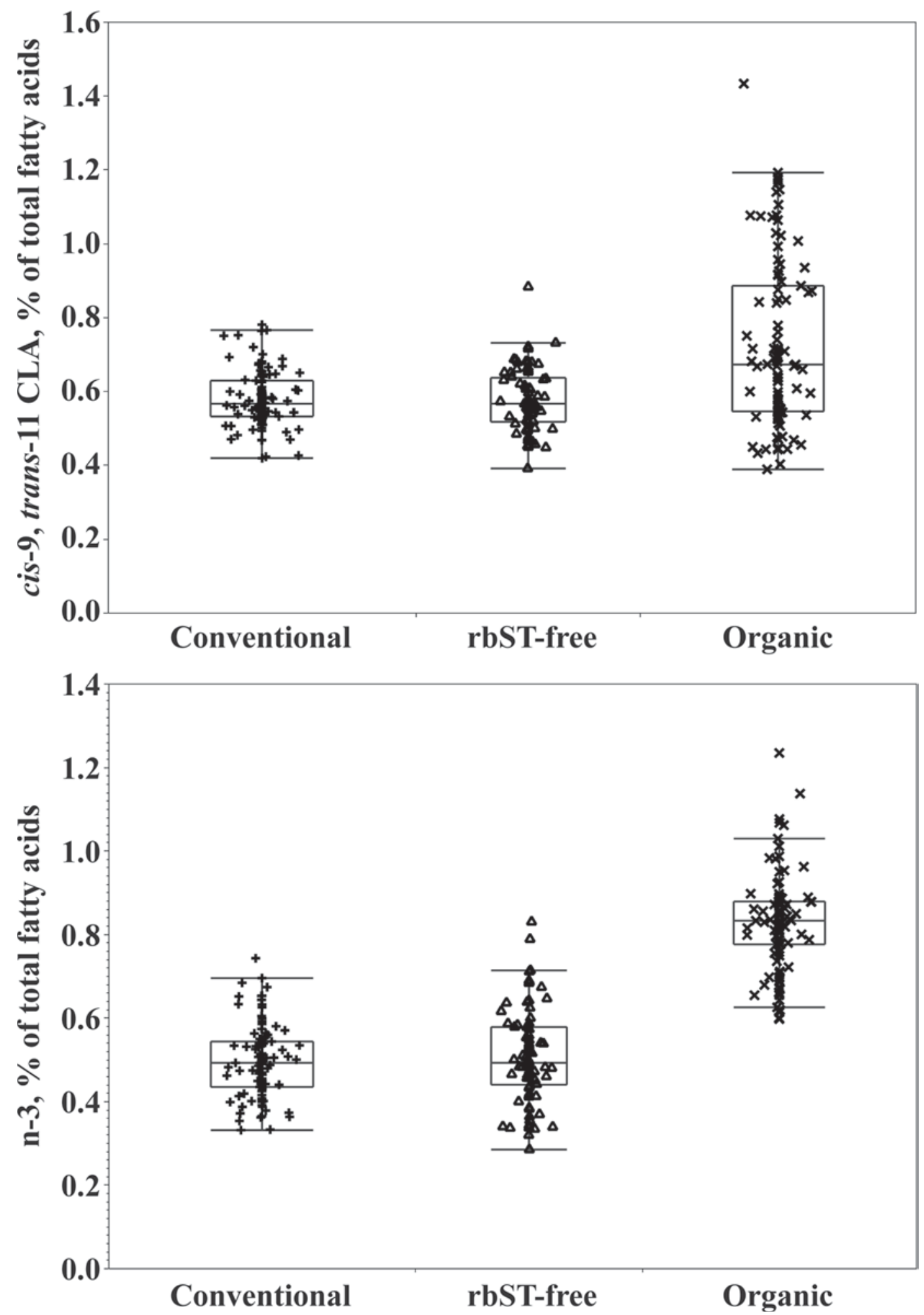

Figure 3. Range of variation for conjugated linoleic acid (CLA) and n-3 fatty acids among conventional milk samples and retail milk samples labeled as recombinant bST (rbST)-free and organic. Box plots display the median (middle line), with the 75th and 25th quartiles above and below (distance between these is the interquartile range). The top and bottom lines represent upper quartile +1.5 interquartile range and lower quartile - 1.5 interquartile range. 
[see reviews by Chilliard et al. (2000) and Bauman and Lock (2006)]. Likewise, the milk fat content of very long chain n-3 PUFA can be enriched by feeding cows supplements of fish oil, algae, or other marine products containing EPA and DHA or dietary supplements containing stearidonic acid (C18:4, n-3) (Palmquist, 2009; Bernal-Santos et al., 2010). Interestingly, increasing the CLA content of milk fat requires incomplete rumen biohydrogenation of PUFA, whereas increasing the n-3 content requires protection of the very long chain PUFA to avoid biohydrogenation. Overall, results from the present study comparing the FA composition of conventional retail milk and milk labeled rbST-free or organic found no meaningful differences that would affect public health. When FA data are combined with previous analyses of these samples (Vicini et al., 2008), results indicate that these specialty labeled milks are similar in nutritional quality and wholesomeness to their conventional counterparts.

\section{REFERENCES}

Arterburn, L. M., E. B. Hall, and H. Oken. 2006. Distribution, interconversion, and dose response of $\mathrm{n}-3$ fatty acids in humans. Am. J. Clin. Nutr. 83(Suppl):1467S-1476S.

Auldist, M. J., J. K. Kay, N. A. Thompson, A. R. Napper, and E. S. Kolver. 2002. Concentrations of conjugated linoleic acid in milk from cows grazing pasture or fed a mixed ration for an entire lactation. Proc. N.Z. Soc. Anim. Prod. 62:240-241.

Bauman, D. E. 1999. Bovine somatotropin and lactation: from basic science to commercial application. Domest. Anim. Endocrinol. 17:101-116.

Bauman, D. E., and A. L. Lock. 2006. Conjugated linoleic acid biosynthesis and nutritional significance. Pages 93-136 in Advanced Dairy Chemistry. Vol. 2: Lipids. 3rd ed. P. F. Fox and P. L. H. McSweeney, ed. Springer, New York, NY.

Bauman, D. E., A. L. Lock, B. A. Corl, C. Ip, A. M. Salter, and P. W. Parodi. 2006. Milk fatty acids and human health: potential role of conjugated linoleic acid and trans fatty acids. Pages 523-555 in Ruminant Physiology: Digestion, Metabolism and Impact of Nutrition on Gene Expression, Immunology and Stress. K. Sejrsen, T. Hvelplund, and M. O. Nielsen, ed. Wageningen Academic Publishers, Wageningen, the Netherlands.

Bergamo, P., E. Fedele, L. Iannibelli, and G. Marzillo. 2003. Fatsoluble vitamin contents and fatty acid composition in organic and conventional Italian dairy products. Food Chem. Toxicol. 82:625-631.

Bernal-Santos, G., A. M. O'Donnell, J. L. Vicini, G. F. Hartnell, and D. E. Bauman. 2010. Enhancing omega-3 fatty acids in milk fat of dairy cows by using stearidonic acid-enriched soybean oil from genetically modified soybeans. J. Dairy Sci. 93:32-37.

Brenna, J. T., N. Salem Jr., A. J. Sinclair, and S. C. Cunnane. 2009. $\alpha$-linolenic acid supplementation and conversion to n-3 long-chain polyunsaturated fatty acids in humans. Prostaglandins Leukot. Essent. Fatty Acids 80:85-91.

Butler, G., J. H. Nielsen, T. Slots, C. Seal, M. D. Eyre, R. Sanderson, and C. Leifert. 2008. Fatty acid and fat-soluble antioxidant concentrations in milk from high- and low-input conventional and organic systems: Seasonal variation. J. Sci. Food Agric. 88:14311441

Capper, J. L., E. Castañeda-Gutiérrez, R. A. Cady, and D. E. Bauman. 2008. The environmental impact of recombinant bovine somatotropin (rbST) use in dairy production. Proc. Natl. Acad. Sci. USA 105:9668-9673.

Chilliard, Y., A. Ferlay, R. M. Mansbridge, and M. Doreau. 2000 Ruminant milk fat plasticity: Nutritional control of saturated, polyunsaturated, trans and conjugated fatty acids. Ann. Zootech. 49:181-205.

Chouinard, P. Y., L. Corneau, D. M. Barbano, L. E. Metzger, and D. E. Bauman. 1999. Conjugated linoleic acids alter milk fatty acid composition and inhibit milk fat secretion in dairy cows. J. Nutr. 129:1579-1584

Christie, W. W. 1982. A simple procedure for rapid transmethylation of glycerolipids and cholesteryl esters. J. Lipid Res. 23:10721075 .

Destaillats, F., J. M. Chardigny, C. Malpuech-Brugère, D. E. Bauman, J. L. Sébédio, J. B. Bezelgues, and F. Dionisi. 2008. Unraveling the complexity of health effects of trans fatty acids: Insight from the TRANSFACT study. Lipid Tech. 20:129-131.

Ellis, K. A., G. Innocent, D. Grove-White, P. Cripps, W. G. McLean C. V. Howard, and M. Mihm. 2006. Comparing the fatty acid composition of organic and conventional milk. J. Dairy Sci. 89:1938-1950

Elwood, P. C., J. E. Pickering, J. Hughes, A. M. Fehily, and A. R. Ness. 2004. Milk drinking, ischaemic heart disease and ischaemic stroke II. Evidence from cohort studies. Eur. J. Clin. Nutr. 58:718-724.

FDA. 2009. Food and Drug Administration, Center for Food Safety and Applied Nutrition. http://vm.cfsan.fda.gov/ dms/qatrans2. html. Accessed September 30, 2009.

Gebauer, S. K., T. L. Psota, W. S. Harris, and P. M. Kris-Etherton 2006. n-3 fatty acid dietary recommendations and food sources to achieve essentiality and cardiovascular benefits. Am. J. Clin. Nutr. 83(Suppl.):1526S-1535S.

German, J. B., and C. J. Dillard. 2006. Composition, structure and absorption of milk lipids: A source of energy, fat-soluble nutrients and bioactive molecules. Crit. Rev. Food Sci. Nutr. 46:57-92.

German, J. B., R. A. Gibson, R. M. Krauss, P. Nestel, B. Lamarche, W. A. van Staveren, J. M. Steijns, L. C. de Groot, A. L. Lock, and F. Destaillats. 2009. A reappraisal of the impact of dairy foods and milk fat on cardiovascular disease risk. Eur. J. Nutr. 48:191-203.

Hara, A., and N. S. Radin. 1978. Lipid extraction of tissues with a low-toxicity solvent. Anal. Biochem. 90:420-426.

Harvatine, K. J., Y. R. Boisclair, and D. E. Bauman. 2009. Recent advances in the regulation of milk fat synthesis. Animal 3:4054.

Huth, P. J., D. B. DiRienzo, and G. D. Miller. 2006. Major scientific advances with dairy foods in nutrition and health. J. Dairy Sci 89:1207-1221

Jakobsen, M. U., K. Overvad, J. Dyerberg, and B. L. Heitmann. 2008 Intake of ruminant trans fatty acids and risk of coronary heart disease. Int. J. Epidemiol. 37:173-182.

Jensen, R. G. 2002. The composition of bovine milk lipids: January 1995 to December 2000. J. Dairy Sci. 85:295-350.

Kelly, M. L., E. S. Kolver, D. E. Bauman, M. E. Van Amburgh, and L. D. Muller. 1998. Effect of intake of pasture on concentrations of conjugated linoleic acid in milk of lactating cows. J. Dairy Sci 81:1630-1636

Kraft, J., M. Collomb, P. Möckel, R. Sieber, and G. Jahreis. 2003 Differences in CLA isomer distribution of cow's milk lipids. Lipids 38:657-664.

Kris-Etherton, P. M., J. A. Grieger, and T. D. Etherton. 2009. Dietary reference intakes for DHA and EPA. Prostaglandins Leukot. Essent. Fatty Acids 81:99-104. doi:10.1016/j.plefa.2009.05.011.

Lavie, C. J., R. V. Milani, M. R. Mehra, and H. O. Ventura. 2009. Omega-3 polyunsaturated fatty acids and cardiovascular diseases. J. Am. Coll. Cardiol. 54:585-594.

Lock, A. L., and D. E. Bauman. 2004. Modifying milk fat composition of dairy cows to enhance fatty acids beneficial to human health. Lipids 39:1197-1206. 
Lock, A. L., P. W. Parodi, and D. E. Bauman. 2005. The biology of trans fatty acids: implications for human health and the dairy industry. Aust. J. Dairy Technol. 60:134-142.

Lock, A. L., C. Tyburczy, D. A. Dwyer, K. J. Harvatine, F. Destaillats, Z. Mouloungui, L. Candy, and D. E. Bauman. 2007. Trans-10 octadecenoic acid does not reduce milk fat synthesis in dairy cows. J. Nutr. 137:71-76.

Mensink, R. P., P. L. Zock, A. D. Kester, and M. B. Katan. 2003. Effects of dietary fatty acids and carbohydrates on the ratio of serum total to HDL cholesterol and on serum lipids and apolipoproteins: A meta-analysis of 60 controlled trials. Am. J. Clin. Nutr. 77:1146-1155.

Molkentin, J. 2009. Authentication of organic milk using delta13C and the alpha-linolenic acid content of milk fat. J. Agric. Food Chem. 57:785-790.

National Research Council. 1989. Diet and Health: Implications for Reducing Chronic Disease Risk. Page 750 in Report of the Committee on Diet and Health, Food and Nutrition Board. National Academy Press, Washington, DC.

National Research Council. 1994. Metabolic modifiers: Effects on the nutrient requirements of food-producing animals. National Academy Press. Washington, DC.

Palmquist, D. L. 2009. Omega-3 fatty acids in metabolism, health, and nutrition and for modified animal product foods. Prof. Anim. Sci. 25:207-249.

Palmquist, D. L., A. D. Beaulieu, and D. M. Barbano. 1993. Feed and animal factors influencing milk fat composition. J. Dairy Sci. $76: 1753-1771$.
Parodi, P. W. 2003. Conjugated linoleic acid in food. Pages 101-122 in Advances in Conjugated Linoleic Acid Research. Vol. 2. J. L. Sébédio, W. W. Christie, and R. O. Adlof, ed. AOCS Press, Champaign, IL

Parodi, P. W. 2009. Has the association between saturated fatty acids, serum cholesterol and coronary heart disease been over emphasized? Int. Dairy J. 19:345-361.

Shingfield, K. J., and J. M. Griinari. 2007. Role of biohydrogenation intermediates in milk fat depression. Eur. J. Lipid Sci. Technol. 109:799-816

Stender, S., A. Astrup, and J. Dyerberg. 2008. Ruminant and industrially produced trans fatty acids: Health aspects. Food Nutr. Res. 52:1-9.

USDA/Agricultural Marketing Service. 2009. National Organic Program. http://www.ams.usda.gov/AMSv1.0/nop. Accessed Sep. 30, 2009.

US Department of Health and Human Services/USDA. 2005. Dietary Guidelines for Americans, 2005. 6th ed. US Government Printing Office, Washington, DC

Vicini, J., T. Etherton, P. Kris-Etherton, J. Ballam, S. Denham, R. Staub, D. Goldstein, R. Cady, M. McGrath, and M. Lucy. 2008. Survey of retail milk composition as affected by label claims regarding farm-management practices. J. Am. Diet. Assoc. 108:1198-1203.

Yashodhara, B. M., S. Umakanth, J. M. Pappachan, S. K. Bhat, R. Kamath, and B. H. Choo. 2009. Omega-3 fatty acids: A comprehensive review of their role in health and disease. Postgrad. Med. J. 85:84-90. 